\author{
Mariola Jarczykowa \\ Uniwersytet Śląski w Katowicach \\ mariola.jarczyk@us.edu.pl
}

\title{
Wierszowana „relacyja” o śmierci Krzysztofa Radziwiłła (1585-1640) z sylwy Andrzeja Lubienieckiego
}

Abstract

A Versed Account of the Death of Krzysztof Radziwiłł (1585-1640) from a Home Chronicle (Sylwa) of Andrzej Lubieniecki

The object of this edition is an anonymous verse Relacyja o żałosnym zejściu Oświeconego Książęcia Krzysztofa Radziwiłła, wojew[ody] wileńs[kieg]o, wielkiego hetmana W[ielkiego] Ks[ięstwa] Litewskie[g]o Anno D[omi]ni 164[0] sub persona Amin[tasa] i Dafn[isa] rozmawiajacych [An account of the lamentable death of His Grace Prince Krzysztof Radziwiłł, the Vilinian Voivode, Great Hetman of the Grand Duchy of Lithuania Anno Domini 1640 given by the persons of Amintas and Dafnis talking with each other] preserved in a home chronicle (so-called sylwa) of Andrzej Lubieniecki, today kept in the collection of the Central Library of Rotterdam (manuscript no. 527).

With regard to its genre qualities, the work may be ascribed to funeral pastorals due to its composition, versification and the names of characters referring to Virgil's bucolics. One of the characters is named Melibeus, which refers to the $1^{\text {st }}$ eclogue ofMaron, in which a shepherd going by the same name bids farewell before his departure for banishment, which may have been a parallel of the Hetman's death. The loss of the Vilnian Voivode is discussed and mourned by Amintas and Dafnis, who were famous in the antique bucolics for their impressive poetical talent. The author freely uses pastoral and mythological motives, joins pagan and Christian religious plots and refers to specific realities and personal details, as well as precisely indicates 
the geographical location of the shepherds: near to Birż, the ancestral residence of the Radziwiłł family, were Dafnis learned about Radziwiłł's death at a market.

The work's title announces the presentation of the death of the Vilnian Voivode, but information about this event are limited only to the time of Krzysztof Radziwiłł's death and a short mention of the reaction of his closest relatives.

The main part of the work is carmen amoebaeum, that is a song performed alternately by shepherds introduced in the title. The subsequent parts of the song commemorate specific merits of Krzysztof Radziwiłł, chiefly as an engaged patron of Evangelical Protestants, funding Protestant meetinghouses and schools, and caring of his fellow-believers. The main reason of the mourning, however, was the loss of an active advocate of equality of rights irrespectively of creed, who fought for liberties for men of different religions in the Polish-Lithuanian Commonwealth. The Voivode was also praised for his efforts to facilitate peace, which harmonised well with values emphasised in the bucolics.

Apart from the typical pastoral figures, Amintas' song also quotes mythological characters and fictional motives. The Hetman's death is here mourned by pagan gods Apollo and Neptune, as well as by Echo and Pan, nymphs, dryads, satyrs, and fauns. Even the nature laments his departure. Dafnis' song depicts Radziwiłł's deification on Olympus and provides an account of the meeting of gods, during which they welcome the deceased Hetman in their circle. In Dafnis' opinion, Radziwiłł deserved this honour most of all due to his religious demeanour, which is confirmed by Piety introduced in the pagan otherworld. The last part of the song presents Melibeus, looking down on the Earth and the relatives he left. The vision of eternal happiness of Radziwiłł is supposed to be a consolation for his grief stricken famil. and fellow countrymen. In the conclusion of the pastoral (conclusio), Amintas recognizes the agon of the shepherds to be Dafnis' victory.

Keywords: Radziwiłł Krzysztof, funeral pastoral, manuscript, Central Library of Rotterdam

Śmierć Krzysztofa Radziwiłła, wojewody wileńskiego, hetmana wielkiego litewskiego, znalazła odbicie w różnorodnych tekstach. Przebieg pogrzebu księcia został utrwalony w okolicznościowym druku, który wyszedł spod pras oficyny Jana Kmity. Opisano tu poszczególne etapy ostatniej drogi hetmana i zamieszczono kazania wygłoszone na egzekwiach. Jest również wzmianka o tym, że po złożeniu ciała Radziwiłła do grobu i po wysłuchaniu mów „rozrzucano panegyri- 
cos, wiersze różne, epicedia od różnych szkół i ludzi uczonych"1. Rymowane utwory nie zostały wydrukowane przez Kmitę, zachowały się natomiast w przekazach rękopiśmiennych - w przechowywanym we Lwowskiej Narodowej Naukowej Bibliotece Ukrainy im. Wasyla Stefanyka manuskrypcie $\mathrm{z}$ Bavorvianum, w którym skopiowano cykl żałobnych wierszy, składający się z „Lamentu na pogrzeb księcia pana wojewody wileńskiego, hetmana Wielkiego Księstwa Litewskiego napisanego przez Waleriana Gorzyckiego, pisarza natenczas pokojowego” i trzech wierszy: „Korony temuż...”, „Nagrobek” i „Na chorągiew temuż" ${ }^{2}$, oraz w sylwie Andrzeja Lubienieckiego, należącej obecnie do zbiorów Centralnej Biblioteki Rotterdamu (rkps 527), zawierającej sielankę „Relacyja o żałosnym zejściu Oświeconego Książęcia Krzysztofa Radziwiłła, wojew[ody] wileńs[kieg]o, wielkiego hetmana W[ielkiego] Ks[ięstwa] Litewskie[g]o Anno D[omi]ni 164[0] sub persona Amin[tasa] i Dafn[isa] rozmawiających"3.

Ten drugi manuskrypt, w którym zachował się utwór będący przedmiotem niniejszego wydania, liczy 1154 strony $^{4}$ i został następująco scharakteryzowany przez Stanisława Kota: „Jest to silva rerum jedna $\mathrm{z}$ najciekawszych dla historii życia umysłowego i ich [Braci Polskich - M.J.] losów w w. XVII"5. Skopiowano tam między innymi wiersze Zbigniewa i Hieronima Morsztynów oraz Jana Stoiń-

J. Kmita, Proces pogrzebu ś[wietej] pamięci Jaśnie Oświeconego Ksiązęcia Je[g]o Mości na Birżach i Dubinkach p[ana] Krzysztofa Radziwiłła wojewody wileńskiego, hetmana wielkiego W[ielkiego] Ks[ięstwa] L[itewskiego], administratora mohilewskiego, bystrzyckiego starosty, Lubcz: Jan Kmita [1641], k. B r.

2 Zob. M. Jarczykowa, Wiersze żałobne dla Krzysztofa Radziwiłła w sylwie ze zbiorów Bavorovianum we Lwowie, „Napis” 22, (2016), z. 3(40), s. 195-203; Gorzycki W., [Wiersze żałobne], oprac. M. Jarczykowa, „Napis” 22 (2016), z. 3(40), s. 204-215.

3 Za zwrócenie mi uwagi na ten utwór dziękuję dr hab. Marii Barłowskiej, a za udostępnienie mi jego zdjęć - Adrie van der Laan z Centralnej Biblioteki w Rotterdamie.

4 Zob. M. Barłowska, „Pieśni mięsopustne” Jana Stoińskiego - powrót, „Odrodzenie i Reformacja w Polsce" 60 (2016), s. 13.

5 S. Kot, Dysputacyj braci polskich katalog z rękopisu Andrzeja Lubienieckiego młodszego, „Reformacja w Polsce” 9/10 (1939), s. 457. 
skiego. Na stronach 653-656 rękopisu przepisano (bez wskazania autora) utwór „Relacyja o żałosnym zejściu Oświeconego Książęcia Krzysztofa Radziwiłła...”. Epicedium wpisuje się w tradycję sielanek żałobnych ${ }^{6}$, na co wskazują struktura i wersyfikacja wiersza ${ }^{7}$ oraz przywołani $\mathrm{w}$ tytule pasterze, znani między innymi z bukolik Wergiliusza. Bohater utworu nazywany jest Melibeusem, co odsyła czytelnika do I eklogi Marona, w której występujący pod tym imieniem pasterz żegna się z Tytarem przed udaniem się na wygnanie, co z kolei mogło być paralelą dla śmierci hetmana. Stratę wojewody wileńskiego omawiają i opłakują słynący w starożytnych bukolikach $\mathrm{z}$ wielkiego talentu poetyckiego Amintas i Dafnis, wykonujący pieśni żałobne, a także Astakus, dla którego imienia inspiracją mógł być bohater z II idylli Kalpurniusza. Do postaci sielanek antycznych nawiązuje też wspomniany w „Relacyji...” gospodarz Likota ${ }^{8}$.

Tytuł utworu zapowiada przedstawienie śmierci wojewody wileńskiego, jednak informacje o tym smutnym wydarzeniu są ograniczone do podania czasu zgonu i krótkiej wzmianki o reakcji najbliższych na odejście Krzysztofa Radziwiłła. Astakus przekazuje bowiem następujące nowiny napotkanemu Dafnisowi: „Przyszła wieść, ale kiedy, nie wiem sam do końca, / Że wczora dni swe skończeł po zachodzie słońca, / Z ciężkim żalem domowych, którzy omdlewali, / Gdy na niespodzianą śmierć jego patrzali” (w. 57-60). Hetman zmarł w Świadości 19 września 1640 roku, co odnotował w swoim diariuszu jego krewny Albrycht Radziwiłł:

Wojewoda wileński, mój stryjeczny, niekatolik, w nocy w obecności niewielu osób wyzionął ducha z najwyższym żalem Rzeczypospolitej, która opłakiwała stratę tak wielkiego senatora. Śmierć ta mocno ugodziła przy-

6 Zob. A. Krzewińska, Sielanka staropolska, jej początki, tradycje i główne kierunki rozwoju, Warszawa 1979, s. 109-125.

7 Jako odpowiednik bukolicznego heksametru Szymon Szymonowic wprowadził do sielanek trzynastozgłoskowiec 7+6. Zob. ibidem, s. 66 .

8 Por. Lycota - bohater elegii IX z ksiąg pierwszych Jana Kochanowskiego. 
wiązanego doń króla, ale najbardziej dotknęła dysydentów. Ci opłakiwali przywódcę swej sekty i trwożyli się w duchu, że padła podpora ich spraw9 ${ }^{9}$.

Nad śmiercią wojewody rozpaczają też bohaterowie sielanki, którzy dowiedzieli się o jego odejściu. Akcja utworu nie rozgrywa się w arkadyjskiej przestrzeni, tylko w ściśle określonym miejscu niedaleko Birż, rodowej siedziby Radziwiłłów linii protestanckiej, scharakteryzowanych jako miasto słynne w Koronie i na Litwie, w którym przodkowie księcia Krzysztofa zbudowali obronny, dobrze ufortyfikowany zamek, a hetman wyposażył go w armaty. Dafnis podkreślił nie tylko położenie i bogactwa naturalne Birż, lecz także nawiązał do odbywających się tam targów, na których pasterze sprzedają owce, mleko i wełnę. Właśnie tam dowiedział się o śmierci hetmana od Astakusa, który przybył do miasta. Dialog pasterzy ma bardzo emocjonalny charakter, głośno wyrażają oni swój ból z powodu odejścia patrona gwarantującego im szczęśliwe życie w pokoju. Dafnis po usłyszeniu złej nowiny tak opisywał swój stan: „wstały na łbie włosy / Pot wystąpił na czoło zimny na kształt rosy” (w. 6566), z kolei Amintas dodawał: „Odszedłem od pamięci na te słowa twoje, / Krew skrzepła, obumarły prawie członki moje” (w. 77-78). W wypowiedzi Astakusa pojawiły się także emocje negatywne, głównie w apostrofach do Zazdrości cieszącej się ze śmierci hetmana: „A jest-li kto, co z tobą z tego się weseli, / Bogdaj nagle zdechł zaraz i nie wstał z pościeli” (w. 63-64). Używanie dosadnych słów z rejestru mowy potocznej było zgodne z zasadami poetyki sielanki, gdyż w gatunku tym obowiązywały reguły stylu niskiego, chociaż mogło to się kłócić z charakterem wiersza żałobnego.

Zasadniczą część utworu stanowi carmen amoebaeum, czyli naprzemienny śpiew pasterzy wskazanych w tytule utworu. Pierwszy zabiera głos Amintas, tak zachęcony przez towarzysza: „tobie każdy dawa / Przodek w rymach, bo z tobą Apollo przestawa” (w. 89-90).

9 A.S. Radziwiłł, Pamiętnik o dziejach w Polsce, t. 2, przeł. i oprac. A. Przyboś, R. Żelewski, Warszawa 1980, s. 222-223. 
W kolejnych częściach pieśni zostały przypomniane konkretne zasługi Krzysztofa Radziwiłła, przede wszystkim jako zaangażowanego patrona ewangelików, fundującego zbory i szkoły, troszczącego się o swoich współwyznawców. Głównym powodem lamentu była jednak strata aktywnego rzecznika równouprawnienia religijnego, walczącego o swobody różnowierców w Rzeczypospolitej. Echo, powtarzając ludzkie narzekania, wypowiada skargę na tych „co przyczyną są wnętrznej niezgody, / Następując na prawa wolność i sumnienie / Tem, z któremi tak ścisłe mają spokrewnienie" (w. 156-158). W refrenie „Muzy, które na wdzięcznem mieszkacie Parnazie, / Wspomnicie Melibea z płaczem w tak złem razie" kilkakrotnie został wyeksponowany niekorzystny moment odejścia Radziwiłła, co mogło być aluzją do wileńskiego tumultu wyznaniowego z 1639 roku, kiedy to rozgorzał konflikt między katolikami a kalwinistami, zakończony decyzją o likwidacji zboru wileńskiego ${ }^{10}$. Książę Krzysztof, mocno zaangażowany w tę sprawę, bronił dysydentów, odpierał zarzuty przeciwników, co niewątpliwie źle wpłynęło na jego zdrowie i w oczach współczesnych hetmanowi przyspieszyło jego przedwczesną śmierć ${ }^{11}$.

Kolejnym powodem do wychwalania wojewody były jego starania o pokój. W utworze nie wymieniono żadnych sukcesów militarnych Radziwiłła, wręcz przeciwnie, zostały wyeksponowane jego umiejętności dyplomatyczne i mediacyjne, co dobrze współbrzmiało $\mathrm{z}$ wartościami podkreślanymi w bukolikach.

10 Zob. U. Augustyniak, Jeszcze raz w sprawie tumultu wileńskiego 1639 i jego następstwach, „Odrodzenie i Reformacja w Polsce” 50 (2006), s. 169-189.

${ }_{11} \mathrm{~W}$ napisie na srebrnej tablicy, którą przygotowano na pogrzeb Krzysztofa Radziwiłła, znalazła się następująca wzmianka „ob tot actus negociosos, tot vigiles pro Repub[lica] curas tot exantlatos boni pub[lici] causa labores, qui ei animae succum sensim sine sensu imminuerunt, praecipitisque et insperati causa fuerunt fati”. W przekładzie Roberta Sawy „za tak wiele pracowitych działań, tyle przejawów nieustannej troski; tyle trudów poniesionych dla dobra publicznego, które stopniowo, niepostrzeżenie osłabiły siłę ducha i stały się przyczyną szybkiej i niespodziewanej śmierci”. Cyt. za: P. Siestrzencewicz, Laudatio funebris [...] Christophori Radziwit [...], [Lubcz]: Jan Kmita [1641], k. [R]v. 
Oprócz typowego sztafażu sielankowego w pieśni przywołano mitologiczne postacie i motywy fabularne ${ }^{12}$. Śmierć hetmana opłakują: bogowie pogańscy Apollo i Neptun, a także Echo i Pan oraz nimfy, driady, satyrowie i faunowie. Autor sugestywnie przedstawia ich rozpacz, niespokojne ruchy i lamenty, a także narzekania na mitologiczne Jędze, czyli Parki zbyt prędko przecinające nić życia Radziwiłła-Melibeusa. Odejścia wojewody żałuje także przyroda: flora i fauna oraz rzeki. $\mathrm{W}$ relacji podkreślono niekorzystne zmiany w zachowaniu zwierząt i stanie drzew, wykorzystując przy okazji aluzje herbowe do „ptaka Jowiszowego”, czyli Radziwiłłowskiego orła, oraz odwołania do laurów zdobiących czoła zwycięzców. W pieśni Dafnisa również występują motywy mitologiczne. Pasterz, uznawany za wcielenie poetyckiego natchnienia, przedstawia ubóstwienie Radziwiłła na Olimpie i - odpowiadając na pytanie: „Kędy się Melibeus dostał z tych niskości?" (w. 200) - relacjonuje spotkanie bogów i przyjęcie do ich grona zmarłego hetmana. Radziwiłł w opinii Dafnisa zasłużył sobie na ten zaszczyt przede wszystkim swą postawą religijną, co potwierdza wprowadzona do pogańskich zaświatów Pobożność. W ostatniej części pieśni przedstawiony jest Melibeus, który z góry spogląda na ziemię i opuszczonych bliskich. Wizja wiecznej szczęśliwości Radziwiłła ma być konsolacją dla pogrążonej w żałobie rodziny i rodaków. Dafnis zachęca do powszechnej radości, którą powinni wyśpiewać Apollo, Echo i pasterze. Jako jeden $\mathrm{z}$ argumentów przemawiających za lepszym życiem w zaświatach przedstawiona jest wzmianka o „przeklętej Zazdrości”, która towarzyszyła w doczesności wojewodzie. W zamknięciu (conclusio) sielanki agon pasterzy zostaje podsumowany przez Amintasa jako zwycięstwo Dafnisa, którego gładkie wiersze są przeciwstawione „tępym zmysłom" pasterza, wypowiadającego życzenia długiego życia dla uzdolnionego poety.

12 W sielankach polskich autorów często przywoływano motywy fabularne i postacie mitologiczne. Zob. M. Walińska, Mitologia w staropolskich cyklach sielankowych, Katowice 2003. 
Utwór żałobny anonimowego twórcy jest ciekawym przykładem zastosowania konwencji sielankowej do opłakiwania śmierci wojewody wileńskiego. Autor swobodnie posługuje się motywami bukolicznymi i mitologicznymi, łączy pogańskie i chrześcijańskie wątki religijne, odwołuje się do konkretnych realiów i personaliów, dookreśla geograficznie scenerię spotkania pasterzy. Takie ujęcie tematu wyróżnia się z pewnością na tle typowych panegiryków funeralnych XVII wieku.

\section{Bibliografia}

Relacyja o żałosnym zejściu Oświeconego Książęcia Krzysztofa Radziwiłła, wojew[ody] wileńs[kieg]o, wielkiego hetmana W[ielkiego] Ks[ięstwa] Litewskie[g]o Anno D[omi]ni 164[0] sub persona Amin[tasa] i Dafn[isa] rozmawiających, Centralna Biblioteka Rotterdamu, rkps 527, s. 653-656.

Augustyniak U., Jeszcze raz w sprawie tumultu wileńskiego 1639 i jego następstwach, „Odrodzenie i Reformacja w Polsce” 50 (2006), s. 169-189.

Barłowska M., „Pieśni mięsopustne” Jana Stoińskiego - powrót, „Odrodzenie i Reformacja w Polsce" 60 (2016), s. 11-27.

Gorzycki W., [Wiersze żałobne], oprac. M. Jarczykowa, „Napis” 22 (2016), z. 3(40), s. 204-215.

Jarczykowa M., Wiersze żałobne dla Krzysztofa Radziwiłla w sylwie ze zbiorów Bavorovianum we Lwowie, „Napis” 22 (2016), z. 3(40), s. 195-203.

Kmita J., Proces pogrzebu ś[wietej] pamięci Jaśnie Oświeconego Książęcia Je[g] o Mości na Birżach i Dubinkach p[ana] Krzysztofa Radziwitła wojewody wileńskiego, hetmana wielkiego $W$ [ielkiego] $K s$ [ięstwa] $L$ [itewskiego], administratora mohilewskiego, bystrzyckiego starosty, Lubcz: Jan Kmita [1641].

Kot S., Dysputacyj braci polskich katalog z rękopisu Andrzeja Lubienieckiego młodszego, „Reformacja w Polsce” 9/10 (1939), s. 456-458.

Krzewińska A., Sielanka staropolska, jej początki, tradycje i główne kierunki rozwoju, Warszawa 1979.

Radziwiłł A.S., Pamiętnik o dziejach w Polsce, t. 2, przeł. i oprac. A. Przyboś, R. Żelewski, Warszawa 1980, s. 222-223.

Siestrzencewicz P., Laudatio funebris [...] Christophori Radziwit [...], [Lubcz]: Jan Kmita [1641].

Walińska M., Mitologia w staropolskich cyklach sielankowych, Katowice 2003. 


\section{Relacyja o żałosnym zejściu Oświeconego Książęcia Krzyszto- fa Radziwiłła, wojew[ody] wileńs[kieg]o, wielkiego hetmana W[ielkiego] Ks[ięstwa] Litewskie[g]o Anno D[omi]ni 164[0] sub persona ${ }^{13}$ Amin[tasa] i Dafn[isa] rozmawiających}

\section{Ami[ntas]}

Co za troski, Dafnida, zjęły ${ }^{14}$ cię takowe,

Że twarz twą kwaśną widzę, pojrzenie surowe?

Czy Bogom śluby czynisz, czy złorzeczysz komu?

Czy-ć wil. w polu, czy-ć złodziej uniósł owcę z do[mu]?

Dafn[is]

5 Ani ja ślubów nowych w sercu swoim knuję,

Ani źle, mój Aminta, nikomu winszuję.

Jest coś gorszego, co mię niewidomie ${ }^{15}$ dręczy

I ciężej niż kat serce utrapione męczy.

A bodaj beła wszytka trzoda ma zginęła,

10 By tylko zła wieść w mieście swą odmianę wzięła ${ }^{16}$.

$$
\text { Ami[ntas] }
$$

Cóż abo tumult jaki wszczął się w mieście nowy?

Powiedz, proszę, długiemi nie bawiąc mie słowy.

A oraz niech wiem i to, jakie imię dano

Miastu temu, kiedy je naprzód zakładano.

\section{Dafn[is]}

15 Jest miasto starożytne w nadobnej równinie,

Pod którym staw szeroki, z stawu rzeka płynie ${ }^{17}$,

Sławne w Księstwie Litewskim, sławne i w Koronie,

Mając fortecę i wał mocny ku obronie.

Od przodków Melibea ${ }^{18} \mathrm{z}$ dawna założone

20 I potężną armatą od nich opatrzone.

W gruntach płodnych, bo się tam obfitych zbóż rodzi,

13 sub persona - pod postaciami

14 zjęły cię - przejęły cię

15 niewidomie - niewidocznie

16 odmianę wzięła - zmieniła się

17 Birże położone są nad rzekami Apaszcza i Agluona oraz nad jeziorem Szyrwena.

18 W XV wieku Birże przeszły w posiadanie Radziwiłłów po bezpotomnej śmierci Grzegorza Fiedkonica, męża Anny Radziwiłłówny. 
Nawet dyjament, czego milczeć się nie godzi,

Birże rzeczone. Ja tak rozumiem o tobie,

Żeś o nim słychał, tylko chciej przypomnieć sobie.

25 Często tam twój Astakus jeździ na targ z wełną

I bywa dobrej myśli, bo nie gardzi pełną ${ }^{19}$.

$$
\text { Ami[ntas] }
$$

Tegom miasta nie widział, słyszałem nazwisko, ${ }^{20}$

Powiedają, że granic kurlandzkich jest blisko,

A też ledwiem trzy, siła ${ }^{21}$ cztery mego wieku ${ }^{22}$

30 Miasta widział, nie chciało włóczyć się człowieku.

$\mathrm{W}$ domum siadał, na własnym zagonie przestając $\mathrm{c}^{23}$,

$\mathrm{O}$ widzenie miast, zamków budownych ${ }^{24}$ mniej dbając.

$$
\text { Dafn[is] }
$$

Tum ja, kiedy promienie pokazało swoje

Słońce z morza, przypędził na targ owiec dwoje,

35 Chcąc biedy swej połatać, a za grosz ubogi

Sprawić prostej siermięgi ${ }^{25}$, szarafan ${ }^{26}$ niedrogi,

Bo ten stary, jak widzisz, prawie z grzbieta leci,

Aż mię wstyd, gdy mię palcem ukazują dzieci.

Tylko co wnidę ${ }^{27} w$ rynek, obaczę, a ono

40 Nie tak, jako był zwyczaj, towary złożono

Sielskich żonek, chłopskich też kolas ${ }^{28}$ ledwie troje,

Na których do przedania mieli zboża swoje.

Tłum błędny w ulicach tam i sam ${ }^{29}$ się snuje,

Nie inaczej jako gdy ogień się zajmuje ${ }^{30}$.

45 Szmer wstał, pospólstwo zewsząd bieży do gromady,

Strwożywszy się, nie wiedzą skąd by zasiąc rady,

Wątpliwa wieść po miastach lata okolicznych,

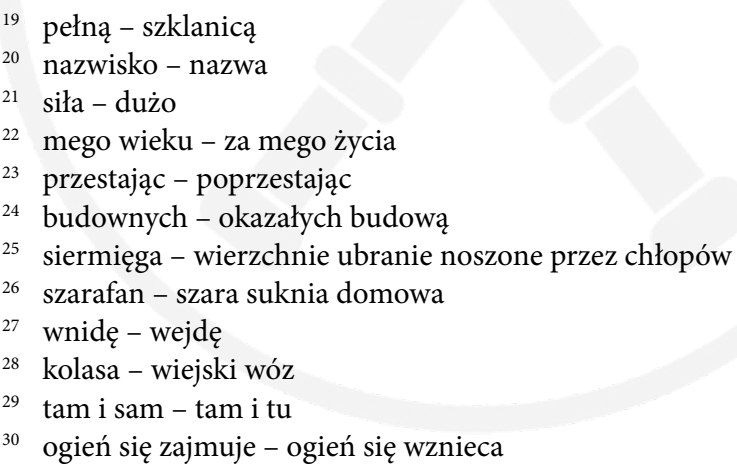


Przeniknąwszy obłoki, sięga niebios ślicznych.

Stanąłem bez pamięci, ${ }^{31}$ strach mię zjął wszytkiego,

50 Pytać się nie śmiem nikogo, co to jest nowego.

Wtem mię potka ${ }^{32}$ Astakus, niosąc na przedanie

Dwie wiedrze mleka, i wnet potkawszy mię, stanie,

Którego temi słowy spytam bojaźliwy:

„Co to za rozruch w mieście, młodzieńcze cnotliwy?”

55 „Ty jeden, mówi, nie wiesz o takim kłopocie:

Nie zstało ${ }^{33}$ Melibea zacnego w żywocie.

Przyszła wieść, ale kiedy, nie wiem sam do końca,

Że wczora dni swe skończeł po zachodzie słońca,

Z ciężkim żalem domowych, którzy omdlewali,

60 Gdy na niespodzianą śmierć jego patrzali.

Ach, toć masz teraz pociech siła ${ }^{34}$ i radości,

Cnocie nieprzyjaciółko, przeklęta Zazdrości!

A jest-li kto, co z tobą $\mathrm{z}$ tego się weseli,

Bogdaj nagle zdechł zaraz i nie wstał z pościeli”.

65 Słysząc tak złą nowinę, wstały na łbie włosy,

Pot wystąpił na czoło, zimny na kształt ${ }^{35}$ rosy.

Wnet zatem puściłem się potem ku domowi

I com słyszał, odniosłem w skok ${ }^{36}$ gospodarzowi,

Likocie, którego znasz; teraz się błąkając,

70 Chodzę, śmierć Melibea $z$ płaczem rozbierając ${ }^{37}$.

Ami[ntas]

Ach, kto tak żelaznego serca, żeby $\mathrm{z}$ tobą

Nie płakał, pomniąc na to, że on beł ozdobą

I murem tego księstwa, w którym przebywamy ${ }^{38}$,

A za jego dzielnością złoty pokój mamy

$75 \quad$ I granice bezpieczne od złego sąsiada?

Dziś życzliwa, dziś zdrowa ustała z nim rada.

Odszedłem od pamięci ${ }^{39}$ na te słowa twoje,

31 bez pamięci - zapominając o wszystkim

32 mię potka - spotka mnie

33 nie zstało - zabrakło

34 pociech siła - dużo pociech

35 na kształt - podobnie jak

36 w skok - bardzo szybko

37 rozbierając - roztrząsając

38 W rękopisie: przebywały.

39 odszedłem od pamięci - zapomniałem o wszystkim 
Krew skrzepła, obumarły prawie członki moje,

Usłyszawszy o śmierci swego dobrodzieja,

80 W którem beła po Bogu wszytkich nas nadzieja.

$$
\text { Daf[nis] }
$$

Nuż tedy, jeśliś w domu uprzątnął zabawy ${ }^{40}$,

Siądźmy tu na zielonej trawie miasto ławy ${ }^{41}$,

A rymy żałosnemi chciej wspomionąc ${ }^{42}$ rzewnie

Zejście Melibeowe, ja-ć pomogę pewnie.

$$
\text { Ami[ntas] }
$$

85 Zaczni ty wprzód w Boży czas, ja z tobą usiędę

I nowej, którąm zrobil, piszczałki dobędę.

$\mathrm{Z}$ rymów też, jakie zdołam, nie chcę się wymawiać,

Tylko na twój początek będę oczekawać.

$$
\text { Daf[nis] }
$$

Ty wprzód zaczni, Aminto, tobie każdy dawa

$90 \quad$ Przodek $^{43} \mathrm{w}$ rymach, bo z tobą Apollo przestawa.

$$
\text { Ami[ntas] }
$$

Zaczynam, niech piszczałka moja brzmi rym smętny,

Który by i potomnem wiekom był pamiętny.

Muzy, które na wdzięcznem mieszkacie Parnazie,

Wspomnicie Melibea $\mathrm{z}$ płaczem $\mathrm{w}$ tak złem razie.

95 Ach, Melibee, leżysz, nad wszytkich mniemanie

Przed czasem uczyniwszy z tym światem rozstanie.

Ach, gdy najpotrzebniejsze pożycie twe beło,

To dni twych nieużyte Fatum dokończeło.

Mniemaliśmy, że twoja pobożność i cnoty

100 Dawne lata przywrócić miały i wiek złoty,

Bo w czyjeż serce nad twe Bóg więcej miłości,

Cnót wszelakich wlał albo świętej pobożności?

Powaga beła w sprawach twoich i w osobie,

W każdej rzeczy roztropnieś postępował sobie.

105 Rozum i sprawiedliwość - te cię sprawowały ${ }^{44}$,

A z drogi przystojności ustąpić nie dały.

Tyś poddane od Boga sobie powierzone

Przy prawach ich zachował w cale nieskrzywdzone,

40 zabawy - zajęcia

41 miasto ławy - zamiast na ławie

42 wspomionąć - wspomnieć

43 dawa przodek - uznaje pierwszeństwo

44 te cię sprawowały - te tobą kierowały 
Swowolnych jako sędzia występki strofując,

110 A dobrych po ojcowsku cnoty koronując.

Muzy, które na wdzięcznem mieszkacie Parnazie,

Wspomnicie Melibea z płaczem w tak złem razie.

Wszyscy po tobie chodzą w żałobie pastuszy,

Płacząc i ciężki smutek piastując na duszy,

115 Którzy za twoją głową szkody nie doznali,

Choć w pola, choć na puszczą trzody swe pognali.

Bełeś zawżdy powodem zgody i pokoju,

Strzegąc się, il. mogło być, krwawego boju.

Częstoś triumf odnosił, szable nie dobywszy,

120 Mądrą nieprzyjacioły radą zwyciężywszy,

Słowoś trzymał. Ojczystych swobód strzegłeś pilnie,

A przy prawie zawsześ się zastawia ${ }^{45}$ usilnie.

Muzy, które na wdzięcznem mieszkacie Parnazie,

Wspomnicie Melibea z płaczem w tak złem razie.

125 Tyś w miastach swych wystawił ozdobne kościoły,

Na cześć Bogu, a przy nich fundowałeś szkoły

Wielkiem kosztem, gdzie słuszne ćwiczenie ${ }^{46}$ młódź brała -

Cóż to, jedno gorliwość twoja sprawowała?

Starałeś się, abyć lud od Boga zlecony,

130 Nie tylko był powszedniem chlebem nakarmiony,

Ale też i na duszy posilone beły

Poddanych twych ${ }^{47}$, a zatem, aby wiecznie żyły.

Każdy potrzebny znał cię hojnem chlebodawcą,

Wiary św[iętej] zawsześ beł statecznym wyznawcą.

135 Nie dbałeś na śmiertelnych ludzi żadne groźby,

Lekceś ważeł namowy, obietnice, prośby,

Stawałeś w takich raziech jak mur niepożytem,

Idąc prawdy zbawiennej gościńcem ubitem.

Muzy, które na wdzięcznem mieszkacie Parnazie,

140 Wspomnicie Melibea $\mathrm{z}$ płaczem w tak złem razie.

Ciebie nimfy nadobne i dryjady z nimi

Obrońce swego płaczą z satyry dzikiemi.

Pan leśny $\mathrm{z}$ faunami po gęstej pustyni

Chodząc, na śmierć okrutną próżną skargę czyni.

145 Apollo po patronie swem ciężko się smuci,

45 przy prawie zawsześ się zastawiał - stałeś zawsze po stronie prawa

46 ćwiczenie - nauki

47 Wersy 131-132 - tekst prawdopodobnie błędnie skopiowany. 
To lutnią w ręce weźmie, to ją zasię rzuci,

Nawet, gorzko westchnąwszy, przeklina złe Jędze ${ }^{48}$,

Że tak nagle doprzędły wieku twego przędze.

Echo lamentów ludzkich słowa powtarzając,

150 Płacze nad głębokimi wały, narzekając:

„Ach, złe dni nastapiły, Melibee drogi,

Śmierć twoja przyniosła nam smutek i żal srogi.

Zwierz wszytek, wszytkie bydła zbiegły w głuche lasy,

Wróżąc nam po twej głowie ${ }^{49}$ nieszczęśliwe czasy.

155 A mniej się bać od sąsiad pogranicznych szkody

Niźli tych, co przyczyną są wnętrznej niezgody,

Następując na prawa, wolność i sumnienie

Tem, z któremi tak ścisłe mają spokrewnienie.

Muzy, które na wdzięcznem mieszkacie Parnazie

160 Wspomnicie Melibea z płaczem w tak złem razie.

Rzeki wszytkie północne, opłakując twoje

Nagłe z światem rozstanie, łez obfitych zdroje

Spuściły bystro w łono oceańskie, zaczem

I sam Neptun obchodził tę smutną wieść płaczem.

165 Ach, i na lasy przyszła narzekania kolej:

Oto $\mathrm{z}$ oliwy więcej nie płynie już olej,

Ale z gałązek onych, z których na twe ciemię

Wieńce wito, dziś brzydka krew płynie na ziemię.

Laury parnaskie miasto ${ }^{50}$ jagód próchno rodzą,

170 Cyprys, jawor, topole bez to włosa chodzą ${ }^{51}$,

Zronii ${ }^{52}$ swoję ozdobę twardy dąb i sośnie,

Palma nie pnie się w górę, ale w ziemię rośnie.

Zioła i kwiatki wonne krasę swą straciły,

Co twoje labirynty rozkoszne zdobiły.

175 Muzy, które na wdzięcznem mieszkacie Parnazie

Wspomnicie Melibea $\mathrm{z}$ płaczem $\mathrm{w}$ tak złem razie.

Łabędź biały po stawie przestronnem pływając,

Żałośnie krzyczy, na śmierć twoję narzekając.

Szpacy, drozdowie, słowik z krzykliwemi kosy

48 Złe Jędze - Parki, w mitologii rzymskiej boginie przeznaczenia, przedstawiane jako prządki, które odmierzały długość ludzkiego życia.

49 po twej głowie - po twojej śmierci

50 miasto - zamiast

${ }^{51}$ bez to włosa chodzą - tekst zapsuty lub inwersja „to bez włosa chodzą"

52 zronił - stracił 
180 Wesołe piosnki w smutne przemienieły głosy.

Ptak Jowiszów ${ }^{53}$, który był herbów twych ozdobą, Płacze, głowę zwiesiwszy i nie władnie sobą.

Ach, jako i domowa czeladź gorzko kwili,

Że pana łaskawego, raczej ojca zbyli.

185 Płaczcież i wy zmarłego Melibea Muzy,

Bo ten czas łzom żałosnem wszytkich wobec służy.

Tu stanę $e^{54}$, bo żal w uściech słowa me hamuje,

A boleść niewymowna serce wskroś przejmuje

Tak, że tego, com zaczął, dokończyć nie można,

190 Chcąc w niebo cnoty twoje wnieść, duszo nabożna.

Przeto już nastąp z swemi, Dafnida, pieśniami,

Który przednim poetą słyniesz między nami,

Ty snadniej ${ }^{55}$ i czasowi, i rzeczom dogodzisz

Jako ten, który wszytkich rymem swem przechodzisz ${ }^{56}$.

$$
\text { Daf[nis] }
$$

195 Żebym rymy przechodził inszych, tego w sobie

Nie czuję, wszakże nie chcąc przeczyć ni w czem ${ }^{57}$ tobie,

Uczynię, co mi każesz, bym tylko mógł chęci

Doznać w swem przedsięwzięciu córek cnej Pamięci ${ }^{58}$.

Powiedzcież, Muzy, usty pełnemi radości

200 Kędy ${ }^{59}$ się Melibeus dostał z tych niskości

I w których od Jowisza gmachach posadzony

Po śmierci, skoro ten świat opuścił znikomy?

$\mathrm{W}$ ten czas, kiedy się rana zorza zajmowała,

A dniowi wesołemu noc ustępowała

205 Jupiter, ociec bogów, król śmiertelnych ludzi,

Zatrząsnąwszy Olimpem, straszne gromy wzbudzi,

Kazawszy się wszytkiemu bóstwu przed się ${ }^{60}$ stawić,

A to przybeło zaraz, nie śmiejąc się bawićc1,

53 ptak Jowiszów - orzeł

54 stanę - przestanę

55 snadniej - łatwiej

56 wszystkich rymem swym przechodzisz - wszystkich przewyższasz umiejętnościami poetyckimi

57 ni w czem - w niczym

58 córek cnej Pamięci - Muz, córek Mnemozyne

59 kędy - gdzie

${ }^{60}$ przed się - przed sobą

61 bawić - zwlekać 
Przyczynę zgromadzenia onego chcąc wiedzieć

210 I czynić, co uradzą. Wtem każą im siedzieć,

A skoro marmorowę zasiedli stolice,

$\mathrm{Z}$ tej strony męskie plemię bogów, $\mathrm{z}$ tej święcice ${ }^{62}$,

Sam Jowisz na majestat ${ }^{63}$ wstąpił uzłocony

Wulkanowej roboty, pyropy sadzony ${ }^{64}$.

215 Jak prędko siadł, stało się głębokie milczenie,

Gdy sceptrum ${ }^{65}$ wziąwszy w rękę, uczynił skinienie,

Którem on morze, ziemię i niebo sprawuje ${ }^{66}$,

Bo sam ludźmi, rybami i słońcem kieruje.

„Do was rzecz ${ }^{67}$ swą obracam - rzekł - święte zebranie ${ }^{68}$,

220 O których ja mam pilną pieczą i staranie,

Z której byście myśl serca mojego pojęli,

Chcę, abyście w swój poczet i liczbę przyjęli

Melibea zacnego plemię starodawne

Walecznych bohatyrów, z przeważnych ${ }^{69}$ dzieł sławne.

225 Ta jest wola ma, na to on swymi cnotami

Zasłużeł, aby wiecznie mógł w niebie żyć z nami".

To rzekszy, uczynił swej mowy dokończenie,

Bo na to samo ${ }^{70}$ zebrał beł to zgromadzenie.

Zgoda zatem stanęła wszytkich, tylko chcieli,

230 Aby się $z$ Melibeem obecnie widzieli.

Wnet $\mathrm{z}$ wolej Jowiszowej w pośrodku stawiony,

Od duchów czystych w białą szatę obleczony,

Bogom twarzą podobny, aniołom odzieniem,

Którego nabeł czystem i wolnem sumnieniem.

235 Tam w liczbę bogów imię jego jest wpisane

I otrzymał w Olimpie miejsce zawołane ${ }^{71}$,

Skąd równy słońcu patrza na nas jasnem okiem,

Gdy po ziemskiem czołgamy okręgu szerokiem,

62 święcice - święte, tu boginie

63 majestat - tu w znaczeniu "tron"

${ }^{64}$ pyropy sadzony - wysadzany klejnotami

${ }_{65}$ sceptrum - berło

${ }_{66}$ sprawuje - kieruje

67 rzecz - mowę

68 zebranie - zgromadzeni

${ }^{69}$ przeważnych - śmiałych, odważnych

70 Bo na to samo - Tylko w tym celu

71 zawołane - sławne 
Gdzie żywot boski żyjąc, widzi przemienione

240 Bohatyry i ludzie cnotliwe wniesione.

Tak z wolej Jowiszowej ma w niebie mieszkanie,

Gdzie żyje i na wieki mieszkać nie przestanie,

Tam, jasnem światłem mając ozdobione czoło,

Od wszytkich obstąpiony bogów jest na koło,

$245 \mathrm{Z}$ weselem niewymownem i $\mathrm{z}$ uszanowaniem,

Co dała znać Pobożność naprzód swym powstaniem,

Mówiąc wszytkich imieniem mieszkających w niebie:

„Szczęśliwy Melibee, ten ma być u ciebie

Poczytany dzień, $\mathrm{w}$ który atoś już jest w święty

250 Chór duchów nieśmiertelnych z radością przyjęty.

Jużeś nasz, bo co się ich w Olimpie najduje

Godnem cię towarzystwa świętego szacuje ${ }^{72 "}$.

To rzekszy, podała mu ochotnie prawicę,

A on zatem ochotnie przywitał święcicę ${ }^{73}$.

255 Wnet potem zgromadzenie ono rozpuszczone,

Skąd poszedł każdy na swe miejsce naznaczone.

Tem czasem Melibeus nieba budynkowi

Pilnie się przypatruje, słońcu, miesiącowi ${ }^{74}$

I gwiazdom jasnem, pięknem porządkiem sadzonem ${ }^{75}$,

260 Więc ${ }^{76}$ planetom w Olimpie ślicznie sporządzonem,

Z góry też często patrząc na ziemskie niskości,

Życzy braciej, ojczyźnie zgody i miłości,

I złotego pokoju, póki będzie trwała

Z wieczną sławą, z ozdobą, którą dotąd miała.

265 Życzy miłej małżonce ${ }^{77}$, aby w późne lata

W dobrem zdrowiu z potomstwem zażywała świata,

Oddając Jowiszowi uniżone dzięki,

Że do nieba wniesiony sprawą możnej ręki

Usiadł z bogi, gdzie pokój z weselem panuje,

270 Gdzie jadu i niechęci złych zimków ${ }^{78}$ nie czuje.

Przeto niechaj już zaraz płacz i narzekanie

72 szacuje - ocenia

73 święcicę - świętą

74 miesiącowi - księżycowi

75 sadzonym - umieszczonym

76 więc - tė̇

77 małżonce - Annie z Kiszków Radziwiłłowej

78 zimków - ziomków 
Wszytkich tych, którzy dotąd kwilili, ustanie,

Owszem, niechaj ten, kleszcząc rękoma, znak dają

Wesela, co pod niebem przestronem ${ }^{79}$ mieszkają.

275 Niech i Muzom parnaskim Apollo uczony

Dopomoże radości, grając w słodkie strony ${ }^{80}$,

Zgoła niechaj co żywo imię to wynosi,

Ile Ziemia cnotliwych na grzbiecie swem nosi.

I Echo, co dopiero smętny głos dawało,

280 Niechaj by się tem głosem wesołem ozwało:

„W niebie masz swe pałace, Melibee drogi,

Zdrad ludzkich wolnem będąc, zasadzek i trwogi

Które na cię przeklęta Zazdrość zastawiała,

Lecz cię sideł jej skrytych cnota zachowała ${ }^{81}$.

285 I my pasterze, jeśli podłych naszych pienie

Piszczałek może w jakiej u ludzi być cenie,

Głośno sławić będziemy twe chwalebne dziła

I tytuły wysokie, którycheś miał siła,

I co się ludzi znajdzie ${ }^{82}$ wdzięcznych być tej chęci,

290 Nie wynidzie imię twe zacne $z$ ich pamięci.

$$
\text { Amin[tas] }
$$

Nie tak przyjemny w parne dni jest w chłodnem cieniu

Sen dany spracowanem żeńcom ku wytchnieniu

I nie tak podróżnemu siła da ochłody

W pragnieniu z skały bystro zdrój płynącej wody,

295 Jaką mają uciechę w sobie rymy twoje.

Oby się w tem rzemieśle tępe zmysły moje

Obierając, mogły tak gładkie wiersze stawić,

Nie chciałbym się pasterstwem śmierdzących kóz bawić,

Ale bym się odważył na wysokie dziéło,

300 Które by poważnego rymu godne beło.

A wy, Muzy uczone, takiemu poecie

Pozwólcie z łaski swojej długo żyć na świecie.

79 przestronym - przestronnym

80 strony - struny

81 zachowała - uchroniła

82 W rękopisie: znajduje. 
Komentarz edytorski

Podstawą edycji tekstu jest przekaz wiersza znajdujący się w rękopisie Centralnej Biblioteki Rotterdamu, sygn. 527, s. 653-656. W transkrypcji tekstu przyjęto następujące zasady:

$\mathrm{W}$ nawiasach kwadratowych rozwinięto skróty w tytulaturze oraz imiona bohaterów (usuwając znaki skrótów - dwukropki).

Zmodernizowano interpunkcję.

Zastosowano dzisiejsze reguły pisowni wielkich i małych liter, a także pisowni łącznej i rozdzielnej, wyjątek czyniąc dla rozdzielnej pisowni tem czasem. Wielkie litery zachowano na początku wersów.

Partykułę -li oraz partykułę w użyciu zaimkowym $c i /-c ́$ pisano z dywizem (jest-li,czy-ć), a końcówki osobowe np. $w$ domum, tum - razem.

Pisownia spółgłosek dźwięcznych i bezdźwięcznych została dostosowana do norm współczesnych, np. bydź|| być, roskoszne \| rozkoszne. Ze względu na rym zachowano oboczne formy Parnazie \| parnaskie.

Pisownię samogłosek $o$, ó, $u$ sprowadzono do dzisiejszej postaci, na przykład pułnocne \|| pótnocne, zachowano jednak formę marmorowę (= marmurową).

Zachowano pochylone $e$, zapisywane w podstawie wydania jako $i$ w parach rymowych: $d z i ł a$, oraz zwężone $e$ do $y$ przed spółgłoską np. bohatyrów.

Zmodernizowano również zapis głosek $i, j, y$ (poza wyrazami obcego pochodzenia, w których zachowano grupy $-y j-$-, -ij-, na przykład relacyja).

Respektowano końcówki narzędnika i miejscownika l. poj. r. m. in. oraz narzędnika l. mn. przymiotników i zaimków -em, -emi, na przykład krzykliwemi, któremi, oraz dawne imiesłowowe końcówki -szy, na przykład rzekszy.

Zachowano i ujednolicono pisownię mie, mię (= mnie).

Bez rozszerzenia zachowano formy: rana (= poranna), przestronem (= przestronnym) oraz formy trybu rozkazującego, na przykład wspomnicie (= wspomnijcie).

Utrzymano formy: sumnienie, zstało, braciej (= braciom). 